\title{
TANGGUNG JAWAB SOSIAL PERUSAHAAN PADA INDUSTRI ROKOK
}

\author{
Ahmad Rizal Solihudin, Bagus Gumelar \\ Universitas Ahmad Dahlan, Yogyakarta
}

\begin{abstract}
This study aims to map and analyze the performance of corporate social responsibility in the cigarette industry. This is done to assess the extent of the cigarette industry's contribution to the social aspects with the company's value benchmark. This research is a quantitative research using content analysis method. The unit of analysis in this study is the annual report of tobacco companies listed on the BEI. The results showed that market valuation had a significant effect on the performance of the social responsibility of cigarette companies in Indonesia on aspects of labor and human rights. In addition, the distribution of social responsibility contributions was less optimal so there needed to be rules that technically direct the activities of tobacco companies so that the benefits are acceptable to all stakeholders optimally.
\end{abstract}

Keywords : cigarette, stakeholder, social responsibility.

Correspondence to : arsolihudin@gmail.com

\section{ABSTRAK}

Penelitian ini bertujuan memetakan dan menganalisis kinerja tanggung jawab sosial perusahaan padaindustri rokok.Hal ini dilakukan untuk menilai seberapa jauh kontribusi industri rokok pada aspek sosial dengan tolak ukur nilai perusahaan. Penelitian ini merupakan penelitian kuantitatif dengan menggunakan metode analisis konten. Unit analisis dalam penelitian ini adalah laporan tahunan perusahaan rokok yang terdaftar pada BEI. Hasil penelitian menunjukkan bahwa penilaian pasar berpengaruh signifikan terhadap kinerja tanggung jawab sosial perusahaan rokok di Indonesia pada aspek tenaga kerja dan hak asasi manusia.Selain itu, pemerataan kontribusi tanggung jawab sosial kurang optimal sehingga perlu ada aturan yang secara teknis mengarahkan aktifitas tanggung jawab sosial perusahaan rokok agar manfaat dapat diterima semua stakeholder secara optimal.

Kata kunci :rokok;stakeholder;tanggung jawab sosial.

Korespondensi : arsolihudin@gmail.com

\section{PENDAHULUAN / INTRODUCTION}

Industri rokok terus berkembang ditengah tekananberkaitan dengan kontroversi efek buruk produknya.Pihak-pihak penggiat anti rokok baik lembaga maupun individu terus mensosialisasikan bahaya rokok bagi kesehatan.Pemerintah pun telah mengeluarkan berbagai aturan yang bertujuan membatasi dan mengendalikan konsumsi rokok. Bahkan, Muhammadiyah sebagai 
organisasi keagamaan Islam mengeluarkan fatwa haram terhadap rokok.Di sisi lain, industri rokok masih dianggap sebagai salah satu penopang stabililitas ekonomi Indonesia. Hal ini berkaitan dengan perannya dalam menyediakan lapangan kerja, pemasukan pajak untuk pemerintah dan kontribusi sosial.

Isu berikutnya yang muncul adalah seberapa jauh aktifitas perusahaan rokok berkontribusi terhadap aspek sosial.Argumen yang digunakan untuk mempertahankan eksistensi perusahaan rokok adalah kontribusi dalam berbagai bidang seperti pendidikan, lapangan pekerjaan, donator aktifitas-aktifitas filantropi, sampai pemberdayaan komunitaskomunitas dan kalangan petani.Semua kontribusi tersebut biasa terangkum dalam aktifitas corporate social responsibility(CSR).Setiap entitas perusahaan mempunyai kewajiban sosial dalam bisnisnya. Kewajiban itu adalah menggunakan seluruh sumber daya untuk menghasilkan profit yang sejalan dengan kepentingan stakeholder (Barnas et al, 2016).

Pada dasarnya penerapan CSR mengharuskan perusahaan tidak hanya memfokuskan semua operasinya untuk keuntungan finansial tetapi juga memperhatikan tujuan sosial dan lingkungan.Berbagai penelitian telah dilakukan untuk menganalisis hubungan antara CSR dengan nilai perusahaan.Emilsson et al (2012) dalam penelitiannya mengemukakan bahwa hasil regresi antara CSR dengan nilai ekonomi perusahaan menunjukkan adanya hubungan yang signifikan antara CSR dan penciptaan nilai ekonomi dalam jangka panjang bagi perusahaan.Tujuan sosial dan lingkungan secara langsung maupun tidak langsung berkaitan dengan kepentingan jangka panjang perusahaan.Peningkatan image perusahaan dimata investor dan konsumen merupakan salah satu bagian dari keterkaitan CSR dengan kepentingan jangka panjang perusahaan (Servaes dan Tamayo, 2013).

Penelitian ini menguji hubungan variabel tanggung jawab sosial yang diproksikan pada tiga tolak ukur sosial meliputi komunitas di dalam perusahaan (karyawan), komunitas di luar perusahaan (masyarakat terdampak proses bisnis) dan hak asasi tiap-tiap individu yang terdampak proses bisnis perusahaan (HAM) dengan variabel nilai perusahaan yang diproksikan return on equity (ROE), ukuran perusahaan dan market value added (MVA). Penggunaan aspek internal,eksternal perusahaan serta HAM sebagai tolak ukur dimensi sosial diharapkan berkontribusi terhadap keterbaruan kajian mengenai tanggung jawab sosial perusahaan.

\section{Profitabilitas (ROE)}

Nilai perusahaan dapat dilihat dari kemampuan manajemen menghasilkan tingkat pengembalian yang tinggi. Profit yang tinggi diharapkan meningkatkan kemampuan perusahaan untuk melakukan aktifitas tanggung jawab sosial lebih baik. Penelitian empiris yang dilakukan Kiran (2015) tentang hubungan antara profitabilitas perusahaan dengan kinerja CSRdi Pakistan. Hasilnya menunjukkan tingkat keuntungan perusahaan berpengaruh signifikan terhadap kinerja CSR. Pendapat ini didukung penelitian Hermawan dan Mulyawan (2014) yang membuktikan bahwa tingkat profitabilitas perusahaan berpengaruh signifikan posifit terhadap kinerja CSR perusahaan.

Ukuran Perusahaan

Aset perusahaan menunjukkan seberapa besar kemampuan perusahaan mengkapitalisasi sumber daya yang dimiliki. Hipotesis yang digunakan adalah semakin besar perusahaan maka kemampuan untuk melakukan aktifitas tanggung jawa sosial semakin besar. Pendapat ini didukung Penelitian Purba dan Yadnya (2015) menjelaskan bahwa ukuran perusahaan dan 
profitabilitas berpengaruh signifikan terhadap kinerja CSR. Hal ini menunjukkan bahwa besar kecilnya ukuran perusahaan berpengaruh terhadap aktifitas CSR. Pendapat ini didukung penelitian Barnas (2016) yang membuktikan bahwa ukuran perusahaan berpengaruh signifikan posifit terhadap kinerja CSR perusahaan. Hal ini menunjukkan bahwa ukuran perusahaan mempunyai korelasi positifdengan kinerja CSR.

Nilai Pasar Perusahaan

CSR menjadi salah satu bentuk tanggung jawab perusahaan yang berkaitan dengan efek-efek yang terjadi akibat aktivitas operasional perusahaan.Semakin banyak bentuk pertanggungjawaban yang dilakukan perusahaan terhadap semakin meningkatkan image perusahaan.Ketika perusahaan mempunyai image pasar yang baik, perusahaan akan cenderung untuk meningkatkan aktifitas sosial untuk menjaga image tersebut (Fiore, 2014).Pendapat ini didasari sudah mulai tumbuhnya perhatianpasar terhadap penerapan operasi perusahaan yang memperhatikan dampak terhadap kondisi sosial dan lingkungan.Hal inilah yang menumbuhkan kesadaran bahwa pihak eksternal (lingkungan dan masyarakat) adalah bagian dari stakeholder yang harus dipenuhi kepentingannya oleh manajemen perusahaan (Retno et al, 2012).

Elemen-elemen kewajiban sosial perusahaan yang berkembang saat ini merujuk pada teori stakeholder yang menyangkut isu sosial dalam kajian manajemen dan bisnis.Teori stakeholder menjelaskan bahwa perusahaan sebagai suatu entitas individu dapat memberi pengaruh dan dipengaruhi oleh berbagai pihak yang disebut stakeholder(Beltratti， 2005).Konsep CSR memandu perusahaan untuk tidak hanya mempunyai tujuan mencari laba (profit) yang merupakan tujuan jangka pendek tetapi juga menjaga kepentingan jangka panjang dengan menerapkan tiga prinsip dasar yang dikenal dengan istilah triple bottom line (profit, people, dan planet). Perusahaan yang mempunyai orientasi jangka panjang menyangkut kelangsungan hidupnya haruslah memperhatikan "3P".Selain mengejar profit, perusahaan juga harus ikut serta dalam pemenuhan kebutuhan kesejahteraan masyarakat (people) dan kelestarian lingkungan (Velasquez, 2012).

Teori lain yang dapat digunakan untuk menjelaskan konsep pengungkapan CSR yaitu teori sinyal (Signaling Theory) yang menjelaskan mengenai kecenderungan perusahaan untuk memberikan informasi kepada pihak eksternal. Hal ini disebabkan karena terjadinya asimetri informasi antara pihak manajemen dan pihak eksternal.Perusahaan harus memberikan pelaporan yang baik untuk mengurangi terjadinya asimetri informasi.Salah satu informasi yang wajib untuk diungkapkan oleh perusahaan adalah kinerja CSRyang biasa dimasukkan dalam laporan tahunan (Fiore, 2014).Global Reporting Initiative (GRI) merupakan sebuah kerangka laporan yang lazim dan diterima untuk mengkombinasikan laporan kinerja keuangan, lingkungan, dan sosial ke dalam satu format yang sama. Berdasarkan pembahasan diatas, dikembangkan sembilan hipotesis sebagai berikut.

H1: Tingkat keuntungan berpengaruh terhadap kinerja CSR Masyarakat

$\mathrm{H} 2$ : Ukuran perusahaan berpengaruh terhadap kinerja CSR Masyarakat

H3: Nilai Tambah Pasar berpengaruh terhadap kinerja CSR Masyarakat

H4: Tingkat keuntungan berpengaruh terhadap kinerja CSR HAM

H5: Ukuran perusahaan berpengaruh terhadap kinerja CSR HAM

H6: Nilai Tambah Pasar berpengaruh terhadap kinerja CSR HAM 
H7: Tingkat keuntungan berpengaruh terhadap kinerja CSR Tenaga kerja

H8: Ukuran perusahaan berpengaruh terhadap kinerja CSR Tenaga kerja

H9: Nilai Tambah Pasar berpengaruh terhadap kinerja CSR Tenaga kerja

\section{METODE PENELITIAN / METHODS}

Jenis penelitian ini termasuk kajianexplanatory dengan menggunakan pendekatan kuantitatif.Data yang digunakan bertipe data paneldiambil dari tahun 2007 sampai tahun 2016. Penelitian menggunakan data sekunder berupa laporan pertanggungjawaban manajemen perusahaan yang dilaporkan setiap tahunnya.Populasi dalam penelitian ini adalah seluruh laporan tahunanperusahaan rokok yang terdaftar di BEI.Teknik pengambilan sampel menggunakan purposive sampling.Pemilihan sampel ini didasarkan pada pertimbangan kelengkapan laporan tahunan perusahaan rokok terutama berkaitan dengan aktifitas CSR.

Instrumen yang dianalisis didasarkan pada ketentuan penerapan CSR yang ditetapkan Global Reporting Initiative (GRI). Data diperoleh dari laporan tahunan, literatur, artikel, dan sumber informasi lain yang berkaitan dengan subyek penelitian.Teknik pengumpulan data menggunakancontent analysis.Teknik ini dilakukan dengan observasi terhadap laporan tahunan perusahaan dan catatan yang ada dalam sumber data yang digunakan.Dalam penelitian ini, corporate social responsibility diproksikan dengan tiga variabel dengan penjelasan sebagai berikut.

\section{CSR Masyarakat}

Semakin

banyak bentuk pertanggungjawaban yang dilakukan perusahaan terhadap semakin meningkatkan image perusahaan. Ketika perusahaan mempunyai image pasar yang baik, perusahaan akan cenderung untuk meningkatkan aktifitas sosial untuk menjaga image tersebut (Fiore, 2014). Laporan perusahaan berkaitan dengan sifat,cakupan, dan keefektifan atas program dan kegiatan apapun yang menilai dan mengelola dampak operasi terhadap masyarakat, termasuk saat memasuki wilayah operasi,selama beroperasi dan pasca operasi.Instrumen yang digunakan untuk mengukur CSR Masyarakat sebanyak 7 item.Rumus perhitungan pengukurannya sebagai berikut.

$$
\text { Social Index }_{\mathrm{j}}=\frac{\sum X_{I j}}{\mathrm{n}_{\mathrm{j}}}
$$

Keterangan:

nj : jumlah item untuk perusahaan $\mathrm{j}$, $\mathrm{nj}=7$

Xij : $1=$ jika item i diungkapkan; $0=$ jika item i tidak diungkapkan

\section{CSR HAM}

Perusahaan mempunyai tanggung jawab memenuhi hak asasi manusia bagi tiaptiap tenaga kerja sejalan juga dengan tidak melanggar HAM tiap-tiap individu di luar perusahaan (Truong, 2010).Dalam hal ini, perusahaan wajib menjamin tidak akan melanggar hak-hak setiap individu manusia yang terkait proses bisnisnya baik di internal maupuneksternal perusahaan. Laporan tahunan menjadi wahana untuk mengkomunikasikan berbagai kebijakan perusahaan berkaitan dengan hak asasi manusia.Instrumen yang digunakan untuk mengukur CSR HAM sebanyak 9 item.Rumus perhitungan pengukurannya sebagai berikut.

$$
\text { Right Index }_{\mathrm{j}}=\frac{\sum X_{I j}}{\mathrm{n}_{\mathrm{j}}}
$$

Keterangan:

nj : jumlah item untuk perusahaan $\mathrm{j}, \mathrm{nj}=9$ 
Xij $\quad: 1=$ jika item i diungkapkan; 0

$=$ jika item i tidak diungkapkan

\section{CSR Tenaga Kerja}

Laporan perusahaan berkaitan dengan ketenagakerjaanyang dihasilkan dan didistribusikan secara langsungmeliputi komposisi tenaga kerja, pelatihan-pelaithan yang ditawarkan, serta kompensasi kepada tenaga kerja tetap dan lepas (Truong, 2010). Selain itu laporan berkaitan dengan dampak operasi perusahaan terhadap tenaga kerja termasuk strategi, aktivitas saat ini dan rencana masa depan. Instrumen yang digunakan untuk mengukur CSR tenaga kerja sebanyak sembilan item.Pengukuran dilakukan dengan menggunakan pendekatan dikotomi, yaitu setiap item diberi nilai 1 jika diungkapkan, dan nilai 0 jika tidak diungkapkan.Rumus perhitungan pengukurannya sebagai berikut.

Labor Index $_{\mathrm{j}}=\frac{\sum X_{I j}}{\mathrm{n}_{\mathrm{j}}}$

Keterangan:

nj : jumlah item untuk perusahaan $\mathrm{j}$, $\mathrm{nj}=14$

Xij : 1 = jika item i diungkapkan; $0=$ jika item i tidak diungkapkan

Variabel nilai perusahaan sebagai variabel independen diproksikan dengan tiga instrument yaitu return on equity (ROE), ukuran perusahaan dan market value added (MVA) dengan penjelasan sebagai berikut. Return on Equity
Return on equity (ROE) merupakan perbandingan antara laba bersih dengan jumlah modal sendiri persahaan. ROE adalah bagian dari salah satu rasio profitabilitas yang sering digunakan untuk mengukur nilai perusahaan. Rumus ROE sebagai berikut.

\section{Ukuran Perusahaan}

$$
\mathrm{ROE}=\frac{\text { Laba Bersih }}{\text { Total Ekuitas }}
$$

Ukuran perusahaan digunakan sebagai variabel independen karena merupakan salah satu faktor yang telah terbukti mempengaruhi kinerja tanggung jawab sosial. Ukuran perusahaan dalam penelitian ini dinyatakan dalam bentuk logaritma natural (ln) dari total asset. Skala yang digunakan adalah skala rasio.

\section{Market Value Added(MVA)}

$$
\text { MVA }
$$

mencerminkanseberapabesarnilaitambahyang berhasildikapitalisasidanmemperbesar nilai kapital perusahaan.NilaitambahpasarMVA darisebuah perusahaan merupakanhasildari selisihnilaipasarperusahaandikurangiseluruh komponen biaya yang dikeluarkan untuk modal investasinya (Brigham dan Houston, 2010).PerhitunganMVAadalah sebagai berikut.

MVA = Market value ofequity-Equity capitalsupplied byshareholders

Secara rinci variabel operasional yang digunakan dalam penelitian ini disajikan dalam tabel 1 sebagai berikut.

Tabel 1 Variabel Operasional

\begin{tabular}{|llll|}
\hline Variabel & Konsep Variabel & Indikator & Skala \\
Independen I & Return on Equity Ratio & $\frac{\text { Laba Bersih }}{\text { Total Ekuitas }}$ & Rasio \\
Independen II & Ukuran Perusahaan & Total asset (ln) & Rasio \\
Independen III & Market Value Added & $\begin{array}{l}\text { Market Value of Equity } \\
- \text { Book Value of Equity }\end{array}$ & Rasio
\end{tabular}




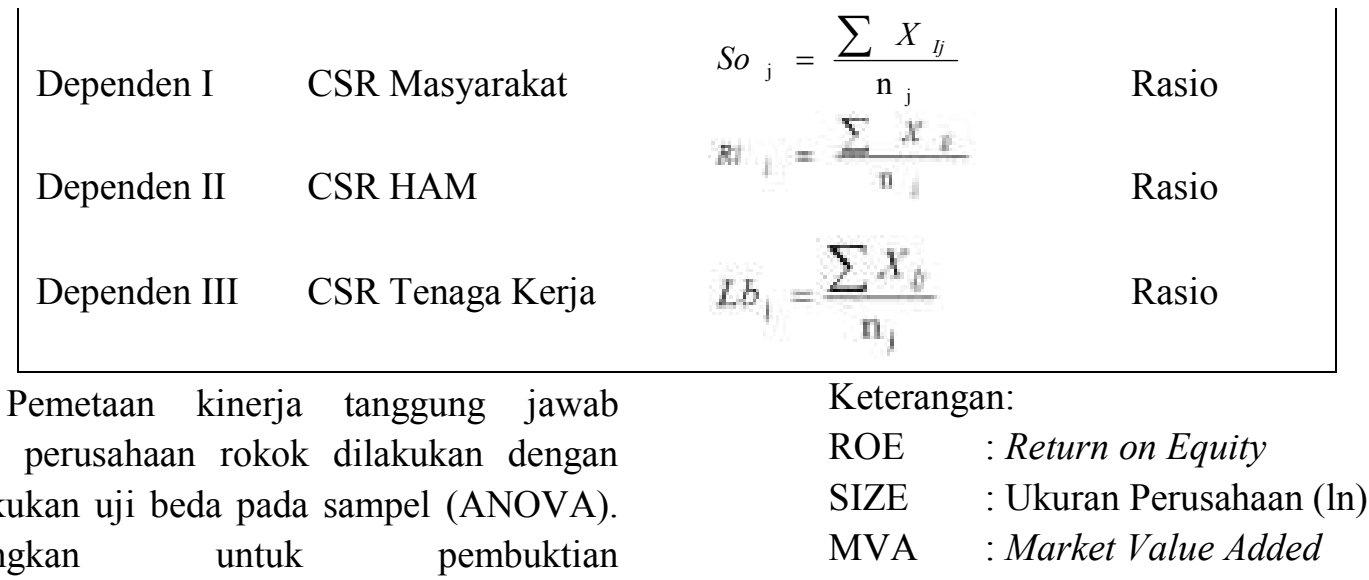

hipotesis,dilakukan uji multiple

regressiongunamengetahui hubungan antara variabel independen dan dependen.Terdapat tiga model regresi berdasarkan variabel operasional yang digunakan untuk menguji hipotesis sebagai berikut.

CSR Masyarakat $=\beta_{0}+\beta_{1}$ ROE $_{\mathrm{it}-1}+\beta_{2}$
SIZE $_{\mathrm{it}-1}+\beta_{3}$ MVA $_{\mathrm{it}-1}+\varepsilon_{\mathrm{t}}$

CSR HAM $=\beta_{0}+\beta_{1}$ ROE $_{\text {it-1 }}+\beta_{2}$

SIZE $_{\text {it-1 }}+\beta_{3}$ MVA $_{\text {it-1 }}+\varepsilon_{\mathrm{t}}$

CSR Tenaga Kerja $=\beta_{0}+\beta_{1} \operatorname{ROE}_{\mathrm{it}-1}+$ $\beta_{2}$ SIZE $_{i t-1}+\beta_{3}$ MVA $_{i t-1}+\varepsilon_{t}$

\section{HASIL PENELITIAN / RESULTS}

Penelitian ini menggunakan 34 laporan tahunan perusahaan rokok sebagai obyek analisis.yang diambil dalam periode 10 tahun dari tahun 2007 sampai tahun 2016.Laporan tahunan tersebut diperoleh dari perusahaan rokok yang terdaftar di BEI.Kriteria pemilihan sampel dalam penelitian ini didasarkan pada kelengkapan data laporan perusahaan.Hasil perhitungan statistik deskriptif dari variabel-variabel yang digunakan disajikan dalam tabel 2.

Tabel 2 Hasil Perhitungan Statistik Deskriptif

\begin{tabular}{|lllll|}
\hline & Minimum & Maximum & Mean & Std. Deviation \\
Nilai Perusahaan & & & & \\
MVA & $-10,610$ & 19,820 & 15,80903 & 7,022044 \\
ROE & $-1,757$ & 0,783 & 0,22012 & 0,518259 \\
SIZE & 14,025 & 17,967 & 16,34565 & 1,259820 \\
CSR & & & & \\
SCR Tenaga Kerja & 0,500 & 0,929 & 0,75426 & 0,128404 \\
CSR HAM & 0,444 & 0,778 & 0,59494 & 0,115872 \\
CSR Masyarakat & 0,571 & 0,857 & 0,69718 & 0,098097 \\
\hline
\end{tabular}

Sumber: Hasil Pengolahan Data

Nilai rata-rata CSR tenaga kerja sebesar 0,75 (nilai maksimal satu) menunjukkan $75 \%$ item pelaporan CSR tenaga kerjadisampaikan oleh perusahaan. Nilai ini lebih besar dari $50 \%$ yang berarti lebih banyak elemen indikator CSR yang telah dilaporkan perusahaan dibanding yang kosong. Kondisi yang sama juga terjadi pada variabel proksi CSR lain. Nilai standar deviasiCSR Masyarakat sebesar 0,09 
menunjukkan aktifitas tanggung jawab sosial setiap perusahaan rokok memiliki kemiripan dalam aspek kemasyarakatan.

Dari tabel 2 terlihat pula bahwa aktifitas tanggung jawab sosial perusahaan rokok masih belum merata.Kontribusi terhadap pihak internal (tenaga kerja) menjadi aspek utama perusahaan rokok dalam menjalankan aktifitas tanggung jawab sosial.Aktifitas CSR berkaitan dengan tenaga kerjarata-rata tercapai $75 \%$ dari indikator penilaiannya.Sedangkan pihak eksternal (masyarakat) dan aspek HAM masih kurang dari $70 \%$.Hal ini menunjukkan perusahaan rokok masih belum merata dalam menjalankan tanggung jawab sosial kepada semua stakeholder sosial.

Langkah berikutnya untuk memetakan aktifitas tanggung jawab sosial dengan melakukan uji beda terhadap variabelvariabel CSR. Langkah ini dilakukan untuk menganalisis perbedaan kinerja CSR untuk masing-masing aspek sosial.Uji beda dilakukan dengan uji repeated ANOVA. Hasil pengujian tersaji dalam tabel 3.

Tabel 3 Uji Beda Variabel CSR

\begin{tabular}{|llc|}
\hline Variabel & Statistic & Sig. \\
SR for CSR Tenaga kerja & 0,910 & 0,008 \\
SR for CSR HAM & 0,871 & 0,001 \\
SR for CSR Masyarakat & 0,800 & 0,000 \\
\hline \multicolumn{2}{l}{ Sumber: Hasil Pengolahan Data } \\
\hline
\end{tabular}

Hasil pengujian ANOVA membuktikan bahwa ketiga variabel proksi tanggung jawab sosial signifikan berbeda. Hal ini ditunjukkan dengan nilai signifikansi ketiga varabel kurang dari 0,05 (derajad kepercayaan 95\%). Dengan demikian dapat disimpulkan bahwa kinerja tanggung jawab sosial perusahaan rokok tidak sama untuk aspek tenaga kerja, HAM dan masyarakat. Perbedaan kinerja menunjukkan bahwa aktifitas tanggung jawab sosial perusahaan rokok masih belum merata secara optimal.

Peraturan tentang CSR di Indonesia telah tersusun dalam Undang-Undang No. 40 Tahun 2007 tentang Perseroan Terbatas.Pasal 74 dalam undang-undang tersebut menguraikan tentang tanggung jawab sosial khususnya bagi perseroan yang usahanya di bidang dan/atau berkaitan dengan sumber daya alam. Selain itu, secara khusus CSR juga diatur dalam Peraturan Pemerintah Nomor 47 Tahun 2012 tentang tanggung jawab sosial dan lingkungan. Salah satu aturan dari peraturan ini adalah kewajiban perusahaan untuk melaporkan pertanggungjawaban sosial yang dilakukan dalam laporan tahunan.Secara tidak langsung aturan ini berimbas pada kewajiban penerapan CSR bukan hanya tindakan sukarela atau carity dari perusahaan.

Peraturan-peraturan tersebut $\mathrm{di}$ atas belum secara spesifik memberi arahan kepada perusahaan mengenai teknis dan sasaran dari aktifitas CSR.Kondisi ini mengakibatkan aktifitas CSR perusahaan tidak terarah dan tidak mempunyai tujuan yang jelas.Selain itu, belum optimalnya aturan teknis juga 
berakibat aktifitas CSR kurang merata memberi manfaat bagi seluruh stakeholder.Hal ini dapat dilihat dari hasil observasi laporan CSR perusahaan rokok yang tidak secara merata menjangkau semua stakeholdersosial.

Perhitungan regresi linier berganda digunakan untuk menganalisis pengaruh MVA, ROE, dan ukuran perusahaan terhadap kinerja tanggung jawab sosial perusahaan.Tabel 4menunjukkan hasil multiple regression yang digunakan untuk menguji sembilan hipotesis yang ada.Dapat dilihat bahwa ROE tidak signifikan memberi pengaruh pada kinerja tanggung jawab sosial perusahaan dengan proksi CSR masyarakat (H1). Selain ROE, dua variabel independen lain yaitu ukuran perusahaan (H2) dan MVA (H3) juga tidak terbukti secara signifikan mempengaruhi kinerja tanggung jawab sosial perusahaan terhadap masyarakat.Hal ini menunjukkan bahwa nilai pasar dengan proksi penilaian pasar modal, ROE dan ukuran perusahaan tidak mempengaruhi kinerja tanggung jawab sosial perusahaan pada aspek sosial masyarakat.

Tabel 4 Hasil Regresi

\begin{tabular}{|llllll|}
\hline Hipoteisis & Variabel & Signifikansi & Prediksi & Empiris & t-Statistic \\
& CSR Masyarakat & & & & \\
H1 & ROE & 0,1202 & + & & $-1,599$ \\
H2 & SIZE & $0,0451^{*}$ & + & - & $-2,091$ \\
H3 & MVA & 0,2923 & + & & $-1,071$ \\
& CSR HAM & & & & \\
H4 & ROE & 0,245 & + & & $-1,185$ \\
H5 & SIZE & 0,159 & + & & $-1,443$ \\
H6 & MVA & $0.002^{*}$ & + & + & 2,356 \\
H7 & CSR Tenaga Kerja & & & & \\
H8 & ROE & 0,181 & + & & $-1,370$ \\
H9 & SIZE & $0,034^{*}$ & + & - & $-2,208$ \\
& MVA & $0,001^{*}$ & + & + & 3,767 \\
\hline
\end{tabular}

*Signifikan pada level 5\%

Sumber: Hasil Pengolahan data

Hasil pengujian $\mathrm{H} 1, \mathrm{H} 2$ dan $\mathrm{H} 3$ menunjukkan bahwa aktifitas tanggung jawab sosial masyarakat perusahaan rokok tidak dipengaruhi nilai perusahaan. Apabila dilihat dari rata-rata nilai CSR masyarakat yang tinggi, terdapat aspek-aspek lain di luar variabel nilai perusahaan yang mempengaruhi kinerja CSR masyarakat. Tidak adanya hubungan signifikan antara CSR masyarakat dan nilai perusahaan kemungkinan disebabkan konsep CSR masyarakatmasih belum menjadi perhatian dalam usaha meningkatkan nilai perusahaan (Fiore,
2014).CSR belum menjadi bagian dari fokus utama perusahaan sehingga perusahaan dengan nilai tinggi maupun rendah mempunyai kinerja tanggung jawab yang tidak berbeda.

Hasil perhitungan yang ditampilkan dalam tabel 4 menunjukkan pengaruh ROE (H4) dan ukuran perusahaan (H5) tidak secara signifikan berpengaruh terhadap kinerja tanggung jawab sosial perusahaan dalam aspek pemenuhan hak asasi manusia. Pengaruh signifikan positif dihasilkan oleh 
variabel MVA sehingga dapat disimpulkan bahwa MVA perusahaan rokok menetukan kinerja tanggung jawab sosial perusahaan dalam aspek pemenuhan hak asasi manusia (H6 terdukung).Pasar sangat sensitif terhadap informasi berkaitan dengan kasus-kasus pelanggaran hak tenaga kerja maupun konflik-konflik dengan individu di luar perusahaan.Semakin tinggi nilai pasar perusahaan, semakin tinggi pula risiko apabila terjadi konflik dengan pihak internal maupun eksternal perusahaan.Hal inilah yang mendorong perusahaan rokok untuk meningkatkan kinerja tanggung jawab sosial pada aspek HAM (Truong, 2010).

Pada model ketiga dengan variabel dependen CSR tenaga kerja, selain MVA, dua variabel independen lain yaitu ROE (H7) dan ukuran perusahaan (H8) tidak signifikan mempengaruhi kinerja tanggung jawab sosial perusahaan dalam aspek tenaga kerja. Pengaruh MVA signifikan positif terhadap mempengaruhi kinerja tanggung jawab sosial perusahaan aspek tenaga kerja dengan nilai signifikansi 0,001 (H9).Akitiftas CSR pada tenaga kerja dapat dilihat sebagai bagian dari apresiasi perusahaan terhadap kinerja tenaga kerja dalam usaha meningkatkan nilai perusahaan.

Hasil pengujian membuktikan bahwa mayoritas hipotesis tidak terdukung.Secara umum hanya variabel MVA yang memberi pengaruh signifikan terhadap kinerja CSR.Hal ini mengindikasikan semakin besar tingkat kepercayaan pasar modal akan semakin meningkatkan motivasi perusahaan rokok untuk menjalankan aktifitas CSR.Apabila dikembalikan pada konsep yang mendasarinya, corporate social responsibility tidak ada kaitannya dengan penyisihan laba.Konsep triple bottom line tidak menuntut perusahaan untuk melakukan aktifitasaktifitas diluar aktifitas operasi perusahaan. Sebaliknya, konsep CSR berusaha mengoptimalkan tujaun dari setiap aktifitas operasi perusahaan termasuk perusahaan rokok tidak hanya berorientasi laba tetapi juga people, dan planet(Velasquez, 2012).Penerapan CSR mengharuskan perusahaan menjadi sebuah entitas bisnis yang tidak hanya memfokuskan semua operasinya untuk keuntungan finansial tetapi juga memperhatikan tujuan sosial dan lingkungan.

Bagi perusahaan rokok, pada dasarnya CSR menjadi salah satu bentuk tanggung jawab berkaitan dengan efek-efek yang terjadi akibat aktivitas operasional perusahaan.Hal inilah yang menumbuhkan kesadaran bahwa pihak eksternal (lingkungan dan masyarakat) adalah bagian dari stakeholder yang harus dipenuhi kepentingannya oleh perusahaan untuk menjaga keberlangsungannya (Fiore, 2014).Penelitian Retno (2012) menunjukkan semakin banyak bentuk pertanggungjawaban yang dilakukan perusahaan terhadap semakin meningkatkan image perusahaan.Selain itu, perusahaan dianggap mempunyai sumber daya yang seharusnya bisa dibagi kepada kepentingan masyarakat dan sosial.Bagi perusahaan sendiri, CSR menjadi salah satu tumpuan mempertahankan eksistensinya.Selain itu, berkembangnya isu etika dalam pengelolaan perusahaan memicu perusahaan untuk lebih serius dalam penerapan CSR(Velasquez, 2012).

\section{KESIMPULAN / CONCLUSSION}

Berdasarkan hasil analisis dan pembahasan dapat disimpulkan beberapa hal sebagai berikut: (1) Variabel ROE tidak terbukti signifikan mempegaruhi kinerja aktifitas CSR pada aspek tenaga kerja, HAM dan kemasyarakatan. (2) Ukuran perusahaan tidak signifikan mempengaruhi kinerja CSR pada perusahaan rokok di Indonesia. (3) Variabel MVA terbukti berpengaruh signifikan positif aktifitas CSR pada aspek tenaga kerja dan HAM. (4) Terdapat 
perbedaan kinerja tanggung jawab sosial pada aspek tenaga kerja, HAM dan masyarakat mengakibatkan pemerataan kontribusi tanggung jawab sosialperusahaan rokok kurang optimal.

\section{SARAN}

Peneliti berikutnya disarankan menggunakan alat ukur lain dalam mengukur kinerja corporate social responsibility. Selain karena analisis konten sangat tergantung kecermatan peneliti dalam menganalisis, penggunaan alat ukut lain akan lebih memperkuat teori yang ada. Selain itu, penelitian padaaspek CSR lain seperti lingkungan dan tanggung jawab produk akanlebih memperluasgambaran perkembangan tren corporate social responsibility di Indonesia.

\section{DAFTAR PUSTAKA / BIBLIOGRAPHY}

Barnas, N. et al. 2016.Pengaruh Profitabilitas dan Ukuran Perusahaan terhadap Pengungkapan CSR.Vol.3(2). eProceeding of Management.

Beltratti, A. 2005.The complementarity between corporate governance and corporate social responsibility. Vol. 30(3).The Geneva Papers on Risk and InsuranceIssues and Practice.

Emilsson, L. et al. 2012. CSR and the quest for profitability-using EVA.Vol. 2(3).International Journal of Economics and Management Sciences.
Fiore, R. 2014. CSR An Empirical Analysis Of Market Value. The Clute Institute International Academic Conference.

Hemawan, S. dan Mulyawan, G. 2014.Profitability and CSR.Vol. 3(1).Asia pacific Journal of Accounting and Finance.

Kiran, S. et al. 2015.CSR and Firm Profitaability.Vol. 5(1).City University Research Journal.

Purba, W. dan Yadnya, P. 2015.Pengaruh Ukuran Perusahaan dan Leverage terhadap Profitabilitas dan Pengungkapan CSR.Vol. 4(8). Ejurnal Manajemen Unud.

Retno, M. et al. 2012.Pengaruh GCG dan pengungkapan CSR Terhadap Nilai Perusahaan.Vol. 1(1). Jurnal Nominal.

Sarvaes, H dan Tamayo, A. 2013. The Impact of CSR on Firm Value. Vol. 59(5).Management Science Informs.

Truong, S. 2010. ASEAN Integration and its Impact on Workers and Trade Unions. Singapore: NUS.

Velasques, M. 2012. Business Ethics. New Jersey: Peasson. 